\title{
OPTIMASI SINTESIS BIOSURFAKTAN KARBOHIDRAT ESTER DARI ASAM PALMITAT DAN FRUKTOSA MENGGUNAKAN ENZIM LIPASE TERIMOBILISASI
}

\section{SYNTHESIS OPTIMATION OF BIOSURFACTANT CARBOHYDRATE ESTERS FROM PALMITIC ACID AND FRUCTOSE BY USING LIPASE ENZYME IMMOBILIZIED}

\author{
${ }^{1}$ Hiskia Arapenta Ginting, ${ }^{1}$ Zuhrina Masyithah, ${ }^{2}$ Tjahjono Herawan, ${ }^{1}$ Denny Samuel Silaen \\ ${ }^{1}$ Departemen Teknik Kimia, Fakultas Teknik, Universitas Sumatera Utara, \\ Jalan Almamater,Medan, 20155, Indonesia \\ ${ }^{2}$ Pusat Penelitian Kelapa Sawit, Jl Brigjen Katamso 51, Medan \\ Email: kiajunior11@gmail.com
}

\begin{abstract}
Abstrak
Karbohidrat ester merupakan salah satu golongan surfaktan nonionik yang banyak dibutuhkan dan berpotensi sebagai surfaktan yang ramah lingkungan. Permasalahan utama dalam sintesis karbohidrat ester adalah memperoleh persen konversi asam palmitat yang optimum dari pengaruh suhu, jumlah biokatalis dan waktu reaksi. Optimasi sintesis karbohidrat ester dilakukan terhadap tiga variabel yang mempengaruhi reaksi esterifikasi. Untuk itu proses esterifikasi dilakukan dengan mereaksikan langsung asam palmitat dan fruktosa menggunakan katalis enzim lipase terimobilisasi Novozyme 435 dengan variabel bebas yaitu suhu reaksi $41,5{ }^{\circ} \mathrm{C} ; 45{ }^{\circ} \mathrm{C} ; 50{ }^{\circ} \mathrm{C} ; 55{ }^{\circ} \mathrm{C} ; 58,4{ }^{\circ} \mathrm{C}$, jumlah biokatalis sebanyak $6,63 \% ; 8 \% ; 10 \% ; 12 \%$; $13,36 \%$ berbasis massa asam palmitat serta waktu reaksi 7,6 jam; 24 jam; 48 jam; 72 jam; 88,3 jam dan direaksikan dengan variabel tetap yaitu kecepatan pengadukan $500 \mathrm{rpm}$; rasio substrat 3:1 (fruktosa : asam palmitat) dan jumlah pelarut $10 \mathrm{ml}$. Campuran kemudian dipisahkan dari katalis secara filtrasi. Produk dianalisis dengan melakukan penentuan bilangan asam untuk memperoleh persen konversi fruktosa ester, penentuan nilai Hydrophilic Liphophilic Balance, spektoroskopi Fourier Transform Infrared (FTIR) dan penentuan tegangan permukaan. Konversi optimum yang diperoleh adalah $61,80 \%$ diperoleh pada kondisi suhu reaksi $55{ }^{\circ} \mathrm{C}$, jumlah enzim Novozyme $4355^{\circledR} 12 \%$ dan waktu reaksi 72 jam. Dari hasil analisa surfaktan fruktosa ester diperoleh nilai HLB 10,592 yang menunjukkan surfaktan fruktosa ester dapat digunakan sebagai pengemulsi minyak dalam air.
\end{abstract}

Kata kunci: karbohidrat ester, asam palmitat, fruktosa, lipase terimobilisasi, optimasi

\begin{abstract}
Carbohydrate ester is one of many needed nonionic surfactant groups and has the potential to be an environmental friendly surfactant. The principal problem in the synthesis of carbohydrate ester is to obtain the optimum conversion of palmitic acid from temperature influence, the amount of biocatalyst and reaction time. The optimization of carbohydrate ester synthesis is carried out on three variables that influence the esterification reaction. Therefore, the esterification process is carried out by reacting directly the palmitic acid and fructose using a Novozyme ${ }^{\circledR} 435$ an immobilized lipase enzyme catalyst with a free variable of reaction temperature of $41,5^{\circ} \mathrm{C}, 45^{\circ} \mathrm{C}, 50^{\circ} \mathrm{C}, 55^{\circ} \mathrm{C}, 58,4{ }^{\circ} \mathrm{C}$, the amount of biocatalyst is $6,63 \%, 8 \%, 10 \%, 12 \%, 13,36 \%$ mass based palmitic acid also reaction time of 7,6 hours; 24 hours; 48 hours; 72 hours; 88,3 hours and reacted with fixed variable in 500 rpm; 3:1 substrate ratio (fructose:palmitic acid) and solvent amount $10 \mathrm{ml}$. The mixture is then separated from the catalyst by filtration. The product was analyzed with determination of acid number to obtain conversion percent of fructose ester, determination of Hydrophilic Lipophilic Balance, Fourier Transform Infrared (FTIR) an surface tension determination. The optimum conversion rate obtained is $61,80 \%$ at $55{ }^{\circ} \mathrm{C}$ of reaction temperature, Novozyme $\AA^{4} 35$ enzyme count is $12 \%$ and 72 hours of reaction time. From the result of fructose ester surfactant analysis obtained HLB 10,592 value which showed fructose ester surfactant can be used as emulsifier of oil in water.
\end{abstract}

Keywords: carbohydrate ester, palmitic acid, fructose, lipase immobilizied, optimation

\section{Pendahuluan}

Seiring dengan meningkatnya kesadaran akan kesehatan dan lingkungan yang baik, permintaan surfaktan yang mudah terdegradasi dan berbasis tumbuhan sudah banyak diminati oleh masyarakat karena surfaktan yang dihasilkan memiliki kelebihan antara lain 
bersifat terbarukan (renewable resources), lebih bersih (cleaner) dan lebih murni dibandingkan bahan baku berbasis petrokimia [8]. Salah satu surfaktan yang berbasis tumbuhan dan bersifat degradatif di alam adalah surfaktan karbohidrat ester.

Surfaktan karbohidrat ester biasanya disintesis dari reaksi esterifikasi senyawa gula atau gula alkohol dengan asam lemak baik secara kimia maupun menggunakan katalis biologi [16]. Asam lemak yang paling banyak digunakan dalam mensintesis surfaktan ini adalah asam lemak minyak kelapa sawit dimana kandungan asam lemak minyak kelapa sawit sebagian besar terdiri dari asam palmitat $(41,8-$ $46,8 \%)$, asam oleat $(37,3-40,8 \%)$, asam linoleat $(9,1-11 \%)$, asam stearat $(4,2-5,1 \%)$ dan lainnya [2].

Surfaktan karbohidrat ester umumnya dapat diproduksi secara kimia dan metode enzimatik. Sintesis surfaktan karbohidrat ester dengan metode kimia dilakukan pada suhu tinggi sehingga membutuhkan energi yang tinggi dan menghasilkan pencoklatan senyawa pada produk. Penggunaan alkali sebagai katalis dalam sintesa karbohidrat ester secara kimia dapat menimbulkan racun residu yang sulit terdegradasi. Sedangkan sintesis karbohidrat ester dengan metode enzimatik akan menghasilkan reaksi yang lebih spesifik, dikarenakan sifat khusus enzim. Selain itu, sintesis enzimatik dilakukan dalam kondisi yang tidak membutuhkan energi yang tinggi dan jauh menghasilkan produk yang tidak beracun dibandingkan secara kimia [3]. Kelebihan dari surfaktan ini adalah dapat digunakan pada rentang $\mathrm{pH}$ yang luas, biodegradable, lembut dan bersifat noniritasi, baik untuk kulit dan mata, toksisitas rendah dan pembusa yang stabil [10].

Atas dasar pemikiran yang telah dipaparkan, maka perlu dilakukan penelitian sintesis biosurfaktan nonionik karbohidrat ester dari asam palmitat dan fruktosa melalui reaksi esterifikasi dengan menggunakan biokatalis enzim lipase yang terimobilisasi untuk mendapatkan informasi penting mengenai pengaruh suhu, jumlah biokatalis dan waktu reaksi terhadap sintesis surfaktan yang dihasilkan sehingga diperoleh variabel proses yang paling signifikan mempengaruhi perolehan konversi surfaktan yang terbaik.

\section{Teori}

Surfaktan adalah zat yang memiliki sifat menyerap ke antarmuka dan biasanya surfaktan bertindak untuk mengurangi energi bebas antarmuka daripada untuk meningkatkannya.
Surfaktan memiliki karakteristik struktur molekul yang dikenal sebagai struktur amphipathik [14]. Menurut kelompok hidrofilik, surfaktan diklasifikasikan sebagai surfaktan anionik, kationik dan nonionik. Surfaktan anionik adalah surfaktan yang jika berdisosiasi dalam air menjadi ion bermuatan negatif dan ion bermuatan positif dan kepala hidrofilik bermuatan negatif (anion). Surfaktan kationik adalah surfaktan yang jika berdisosiasi dalam air menjadi ion bermuatan negatif dan ion bermuatan positif dan kepala hidrofilik bermuatan positif (kation). Surfaktan nonionik tidak dapat berdisosiasi dalam air dan kepala hidrofilik bermuatan netral [13]. Salah satunya adalah surfaktan karbohidrat ester.Surfaktan karbohidrat ester dapat diproduksi dengan reaksi antara karbohidrat dan asam lemak seperti berikut :

$\mathrm{C}_{\mathrm{n}}\left(\mathrm{H}_{2} \mathrm{O}\right)_{\mathrm{n}}+\mathrm{RCO}_{2} \mathrm{H} \stackrel{\text { Lipase }}{\longrightarrow} \mathrm{C}_{\mathrm{n}}\left(\mathrm{H}_{2} \mathrm{O}\right)_{\mathrm{n}-1}(\mathrm{OCOR})+\mathrm{H}_{2} \mathrm{O}$

Karbohidrat Asam Lemak Karbohidrat Ester Air

Asam lemak yang dipakai dalam mensintesis surfaktan karbohidrat ester ini adalah asam palmitat dimana penggunaan asam palmitat ini sudah banyak digunakan untuk memproduksi sabun, kosmetik [11]. Sedangkan untuk karbohidrat yang digunakan dalam sintesis surfaktan karbohidrat ester ini ialah fruktosa karena mudah ditemukan dalam buah-buahan, madu dan akar sayuran dan juga penggunaannya yang sudah banyak ditambahkan dalam industri makanan dan minuman [7].

Surfaktan karbohidrat ester adalah surfaktan nonionik yang ramah lingkungan, tidak beracun dan tidak menimbulkan iritasi. Surfaktan karbohidrat ester dapat dihasilkan dengan jalur sintesis kimia. Jalur sintesis kimia memerlukan energi yang lebih daripada jalur sintesis enzimatik dan memiliki selektifitas yang rendah. Serta gabungan suhu yang tinggi penggunaan katalis alkali dalam proses kimia menyebabkan perusakan warna pada produk dan membentuk produk yang beracun. Sehingga sintesis menggunakan katalis lipase lebih dipilih untuk memproduksi surfaktan karbohidrat ester [1].

Lipase adalah enzim yang memiliki signifikansi fisiologis yang cukup besar. Lipase mengkatalis hidrolisis triasilgliserol untuk gliserol dan asam lemak. Berbeda pada reaksi ester, lipase bekerja ketika diserap ke antarmuka minyak-air dan tidak menghidrolisis substrat yang dilarutkan dalam cairan. Penggunaan lipase banyak digunakan dalam pengolahan kimia organik, formulasi deterjen, pembuatan 
biosurfaktan, industri oleokimia, industri susu, industri agrokimia, pembuatan kertas, nutrisi, kosmetik dan pengolahan farmasi [15].

Enzim lipase yang digunakan bersifat terimobilisasi. Enzim terimobilisasi adalah suatu enzim yang diperangkap dan dilekatkan pada suatu medium agar enzim dapat lebih tahan lama terhadap perubahan kondisi seperti $\mathrm{pH}$ atau temperatur. Sistem ini juga membantu enzim berada di tempat tertentu selama berlangsungnya reaksi sehingga memudahkan proses pemisahan dan memungkinkan untuk dipakai lagi di reaksi lain. Sistem ini memiliki keunggulan dalam hal efisiensi sehingga di industri banyak digunakan dalam reaksi yang dikatalis oleh enzim [6].

Hal efisiensi lainnya dalam penelitian ini dibantu dengan menggunakan metode Response Surface Methodology atau Metode Permukaan Sambutan yaitu teknik matematika dan statistika yang berguna untuk pemodelan dan analisis masalah utama dimana responnya dipengaruhi oleh beberapa variabel. Tujuannya adalah untuk mengoptimalkan kondisi operasi percobaan yang dilakukan [9].

Untuk menentukan kegunaan surfaktan, maka biasanya terlebih dahulu ditentukan nilai HLB (Hydrophile Lipophile Balance). Nilai HLB untuk emulsifier nonionik dapat dihitung dari komposisi teoritikal atau analisis data. Data yang diperoleh untuk menganalisis biasanya dasar yang lebih baik untuk menentukan nilai HLB. Rumus yang digunakan untuk menghitung nilai HLB yaitu [4] :

$$
\mathrm{HLB}=20 \times(1-\mathrm{S} / \mathrm{A}) .
$$

dimana :

$$
\begin{aligned}
& \mathrm{S}=\text { bilangan penyabunan } \\
& \mathrm{A}=\text { bilangan asam }
\end{aligned}
$$

\section{Metodologi Penelitian \\ Bahan Baku dan Peralatan}

Bahan baku utama dalam penelitian ini adalah asam palmitat, fruktosa, katalis Novozym ${ }^{\circledR} 435$, dimetil sulfoksida, $\mathrm{KOH}$, phenolpthalein dan etanol. Peralatan yang digunakan pada penelitian ini adalah reaktor,magnetic stirrer, corong, tabung reaksi, termometer, erlenmeyer, gelas ukur, kertas saring dan tabung penyimpanan sampel.

\section{Rancangan Percobaan}

Penelitian ini dilakukan dengan variabel bebas yaitu suhu, jumlah biokatalis dan waktu reaksi pada reaksi esterifikasi dengan menggunakan metode permukaan sambutan. Desain Central Composite Design (CCD) pada eksperimen yang menggunakan tiga variabel independen nilai rotabilitasnya $=\left(3^{2}\right)^{1 / 4}=$ $1,6818 \approx 1,682$. Oleh karena itu nilai $\pm 1,682$ termasuk nilai yang digunakan untuk pengkodean. Perlakuan terkode untuk reaksi esterifikasi dapat dilihat pada tabel 1 .

Tabel 1. Perlakuan Terkode Reaksi Esterifikasi

\begin{tabular}{|l|c|c|c|c|c|}
\hline \multirow{2}{*}{ Perlakuan } & \multicolumn{5}{|c|}{ Perlakuan Terkode } \\
\cline { 2 - 6 } & $\mathbf{- 1 , 6 8}$ & $\mathbf{- 1}$ & $\mathbf{0}$ & $\mathbf{1}$ & $\mathbf{1 , 6 8}$ \\
\hline Suhu $\left({ }^{\circ} \mathrm{C}\right)$ & 41,5 & 45 & 50 & 55 & 58,4 \\
\hline $\begin{array}{l}\text { Jumlah } \\
\text { Biokatalis (\%) }\end{array}$ & 6,63 & 8 & 10 & 12 & 13,3 \\
\hline $\begin{array}{l}\text { Waktu Reaksi } \\
\text { (Jam) }\end{array}$ & 7,6 & 24 & 48 & 72 & 88,3 \\
\hline
\end{tabular}

Untuk mendapatkan konversi asam palmitat yang maksimum pada penelitian ini, variabel bebas divariasikan dalam Central Composite Design seperti dapat dilihat pada tabel 2 dan diperoleh variasi sebanyak 20 run.

\begin{tabular}{|c|c|c|c|}
\hline No & $\begin{array}{l}\text { Suhu } \\
\left(\mathbf{X}_{1}\right)\end{array}$ & $\begin{array}{c}\text { Jumlah } \\
\text { Biokatalis } \\
\left(\mathbf{X}_{2}\right)\end{array}$ & $\begin{array}{c}\text { Waktu } \\
\text { Reaksi } \\
\left(\mathrm{X}_{3}\right)\end{array}$ \\
\hline 1 & -1 & -1 & -1 \\
\hline 2 & 1 & -1 & -1 \\
\hline 3 & -1 & 1 & -1 \\
\hline 4 & 1 & 1 & -1 \\
\hline 5 & -1 & -1 & 1 \\
\hline 6 & 1 & -1 & 1 \\
\hline 7 & -1 & 1 & 1 \\
\hline 8 & 1 & 1 & 1 \\
\hline 9 & $-1,682$ & 0 & 0 \\
\hline 10 & 1,682 & 0 & 0 \\
\hline 11 & 0 & $-1,682$ & 0 \\
\hline 12 & 0 & 1,682 & 0 \\
\hline 13 & 0 & 0 & $-1,682$ \\
\hline 14 & 0 & 0 & 1,682 \\
\hline 15 & 0 & 0 & 0 \\
\hline 16 & 0 & 0 & 0 \\
\hline 17 & 0 & 0 & 0 \\
\hline 18 & 0 & 0 & 0 \\
\hline 19 & 0 & 0 & 0 \\
\hline 20 & 0 & 0 & 0 \\
\hline
\end{tabular}

Tabel 2. Central Composite Design untuk Tiga Variabel 


\section{Prosedur Sintesis Surfaktan Karbohidrat Ester}

Proses sintesis yang dilakukan diadopsi dari Neta, dkk., 2011 dimana tahap awal dalam sintesis surfaktan karbohidrat ester dengan melarutkan fruktosa di dalam $100 \mathrm{ml}$ pelarut dimetil sulfoksida (DMSO) sampai kelarutan fruktosa dengan pelarut dimetil sulfoksida menjadi jenuh dan ditimbang berat fruktosa yang terkandung dalam $100 \mathrm{ml}$ pelarut dimetil sulfoksida. Kemudian asam palmitat ditimbang beratnya sesuai dengan rasio molar substrat 1:3 dengan berat fruktosa yang terkandung dalam pelarut ke dalam tabung reaksi. Novozyme ${ }^{\circledR} 435$ ditimbang beratnya sebanyak jumlah tertentu dari berat total substrat ke dalam tabung reaksi. Campuran fruktosa dengan pelarut dimasukkan sebanyak $10 \mathrm{ml}$ ke dalam tabung reaksi bersama asam palmitat dan Novozyme 435 kemudian dimasukkan magnetic stirrer. Campuran direaksikan di dalam reaktor dengan suhu reaksi tertentu kemudian dihomogenkan campuran dengan kecepatan putaran $500 \mathrm{rpm}$ selama waktu reaksi tertentu. Reaktor dimatikan kemudian tabung reaksi dikeluarkan dari reaktor setelah tercapai waktu reaksi kemudian campuran disaring dengan menggunakan kertas saring untuk memisahkan enzim dari larutan. Campuran yang telah disaring kemudian disimpan dalam tabung penyimpanan sementara sampai dilakukan analisis terhadap surfaktan yang dihasilkan [9].

\section{Analisa Hasil Surfaktan Karbohidrat Ester}

Analisa hasil meliputi penentuan bilangan asam, penentuan bilangan penyabunan, analisis tegangan permukaan. Analisis identifikasi senyawa dengan Spektroskopi FT-IR, dan penentuan nilai HLB.

\section{Hasil dan Pembahasan Prediksi Model}

Langkah agar model persamaan yang dibuat tidak menyimpang jauh, tahap awal dalam RSM adalah memprediksi model regresi dan dilanjutkan dengan analisis variansi (ANOVA) dan uji verifikasi model. Model regresi yang dibuat bertujuan untuk mengetahui hubungan antara persen konversi asam palmitat (Y) dengan suhu $\left(\mathrm{X}_{1}\right)$, jumlah biokatalis $\left(\mathrm{X}_{2}\right)$ dan waktu reaksi $\left(\mathrm{X}_{3}\right)$ serta untuk mengoptimalkan respon yaitu konversi asam palmitat. Pada tabel 3 berikut dicantumkan hasil prediksi koefisien regresi untuk menyusun model permukaan sambutan sintesis surfaktan karbohidrat ester.

Berdasarkan hasil analisis statistik pada Tabel 3, dapat dilihat bahwa waktu reaksi memberikan pengaruh yang signifikan sebesar 17,5476 terhadap pembentukan surfaktan karbohidrat ester. Diikuti dengan variabel suhu reaksi sebesar 14,0459 terhadap pembentukan produk surfaktan karbohidrat ester dan jumlah biokatalis memberikan pengaruh sebesar 0,7368. Begitu pula interaksi suhu dengan waktu reaksi memberikan pengaruh sebesar 27,5031 .

Tabel 3. Hasil Prediksi Koefisien Regresi untuk Menyusun Model Permukaan Sambutan Sintesis Surfaktan Karbohidrat Ester

\begin{tabular}{|c|c|c|c|c|}
\hline Term & Coef & $\begin{array}{c}\text { SE } \\
\text { Coef }\end{array}$ & T & $\mathbf{P}$ \\
\hline Constant & 21,6840 & 2,210 & 9,811 & 0,000 \\
\hline Suhu $\left(\mathrm{X}_{1}\right)$ & 14,0459 & 2,466 & 5,696 & 0,000 \\
\hline $\begin{array}{c}\text { Jumlah } \\
\text { Biokatalis } \\
\left(\mathrm{X}_{2}\right)\end{array}$ & 0,7368 & 2,466 & 0,299 & 0,771 \\
\hline $\begin{array}{c}\text { Waktu } \\
\text { Reaksi } \\
\left(\mathrm{X}_{3}\right)\end{array}$ & 17,5476 & 2,466 & 7,116 & 0,000 \\
\hline $\mathrm{X}_{1} * \mathrm{X}_{1}$ & $-3,4497$ & 4,037 & $-0,854$ & 0,413 \\
\hline $\mathrm{X}_{2} * \mathrm{X}_{2}$ & 12,4496 & 4,037 & 3,084 & 0,012 \\
\hline $\mathrm{X}_{3} * \mathrm{X}_{3}$ & 3,4460 & 4,037 & 0,854 & 0,413 \\
\hline $\mathrm{X}_{1} * \mathrm{X}_{2}$ & 0,6042 & 5,419 & 0,111 & 0,913 \\
\hline $\mathrm{X}_{1} * \mathrm{X}_{3}$ & 27,5031 & 5,419 & 5,075 & 0,000 \\
\hline $\mathrm{X}_{2} * \mathrm{X}_{3}$ & 1,8192 & 5,419 & 0,336 & 0,744 \\
\hline
\end{tabular}

$\mathrm{S}=5,418 ; \mathrm{R}-\mathrm{Sq}=92,33 \% ; \mathrm{R}-\mathrm{Sq}(\operatorname{adj})=85,42 \%$

$$
\begin{array}{ll}
\text { Keterangan : } & \\
\text { Coef } & =\text { koefisien model regresi } \\
\text { SE Coef } & =\text { koefisien error model regresi } \\
\mathrm{P} & =\text { nilai uji } \mathrm{P} \\
\mathrm{S} & =\text { kuadrat karena error }: \text { residual } \\
\mathrm{R}-\mathrm{Sq} & =\text { kuadrat total } \\
\mathrm{R}-\mathrm{Sq}(\text { adj) } & =\text { kuadrat karena perlakuan } \\
\mathrm{T} & =\text { nilai parsial } \\
\text { Term } & =\text { hubungan karena perlakuan }
\end{array}
$$

Nilai uji $\mathrm{P}$ digunakan untuk menguji signifikan atau tidaknya hubungan dua variabel. Faktor signifikansi yang digunakan adalah $\alpha=$ 0,05 . Variabel bernilai signifikan jika nilai $\mathrm{P} \leq$ $\alpha$. Sehingga variabel suhu dan waktu reaksi serta interaksi suhu dan waktu reaksi dikatakan signifikan. Berdasarkan Tabel 3, model persamaan yang dapat menunjukkan hubungan variabel reaksi dan interaksinya terhadap persen konversi asam palmitat $\left(\mathrm{Y}_{\mathrm{AP}}\right)$ pada sintesis surfaktan karbohidrat ester diperoleh sebagai berikut :

$\%$ Konversi $=21,6840+14,0459 \mathrm{X}_{1}+$ $17,5476 X_{3}+12,4496 X_{2}+27,5031 X_{1} \cdot X_{3}$ 
dimana $\mathrm{X}_{1}, \mathrm{X}_{2}, \mathrm{X}_{3}$ merupakan suhu reaksi, jumlah biokatalis, dan waktu reaksi.

Nilai koefisien determinasi $\left(\mathrm{R}^{2}\right)$ dari hasil analisis sebesar 92,33\% menunjukkan bahwa variabel bebas pada percobaan berpengaruh pada variabel terikat. Se

\section{Pengaruh Suhu dan Jumlah Biokatalis Terhadap Konversi Fruktosa Ester}

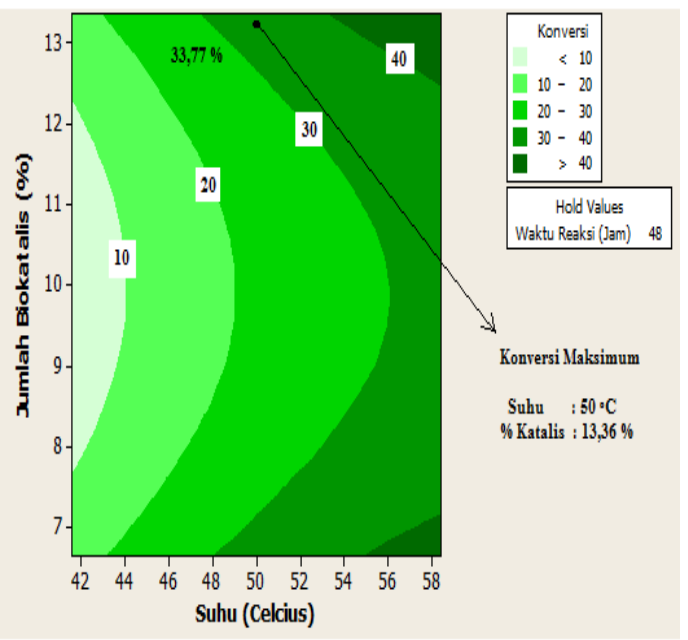

Gambar 1. Respon Kontur dari Plot Suhu dan Jumlah Biokatalis terhadap konversi Asam Palmitat

Plot kontur menunjukkan bahwa jika jumlah biokatalis dipertahankan pada jumlah tertentu dan suhu dinaikkan, maka mampu meningkatkan persen konversi produk surfaktan karbohidrat ester. Tetapi ketika jumlah biokatalis dinaikkan dan suhu dipertahankan konstan, terlihat bahwa hal tersebut sedikit mempengaruhi perolehan konversi pada produk surfaktan karbohidrat ester.

Hal ini karena suhu tinggi dapat meningkatkan laju reaksi karena mengurangi viskositas campuran lipid dan meningkatkan tranfer antara substrat dan produk di permukaan atau di dalam partikel enzim. Namun, suhu tinggi juga dapat mengurangi stabilitas dan separuh umur enzim [17]. Oleh karena itu, dalam melaksanakan penelitian ini digunakan enzim lipase Novozyme®435 karena enzim ini lebih tahan terhadap suhu yang lebih tinggi dibandingkan enzim lipase dengan merek dagang yang lain [12].

Permukaan kontur pada gambar 1 menunjukkan bahwa pada variabel tetap yaitu waktu reaksi 48 jam, konversi maksimum dapat diperoleh apabila suhu reaksi berada pada $50{ }^{\circ} \mathrm{C}$, sedangkan jumlah biokatalis $13,36 \%$. Pada kondisi reaksi ini, dapat diperoleh persen konversi fruktosa ester sebesar $33,77 \%$.

\section{Pengaruh Suhu dan Waktu Reaksi Terhadap Konversi Fruktosa Este}

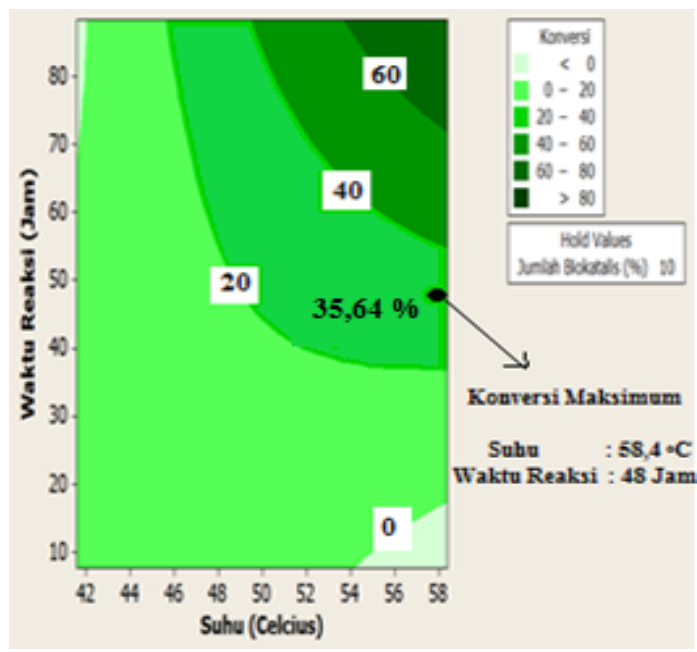

Gambar 2. Respon Kontur dari Plot Suhu dan Waktu Reaksi terhadap konversi Asam Palmitat

Pada Gambar 2 menunjukkan bahwa pada variabel tetap yaitu jumlah biokatalis $10 \%$ diperoleh konversi maksimum apabila suhu berada pada suhu 58,4 ${ }^{\circ} \mathrm{C}$ sedangkan waktu reaksi 48 jam. Pada kondisi reaksi ini diperoleh $\%$ konversi surfaktan karbohidrat ester sebesar $35,64 \%$.

\section{Pengaruh Jumlah Biokatalis dan Waktu Reaksi Terhadap Konversi Fruktosa Ester}

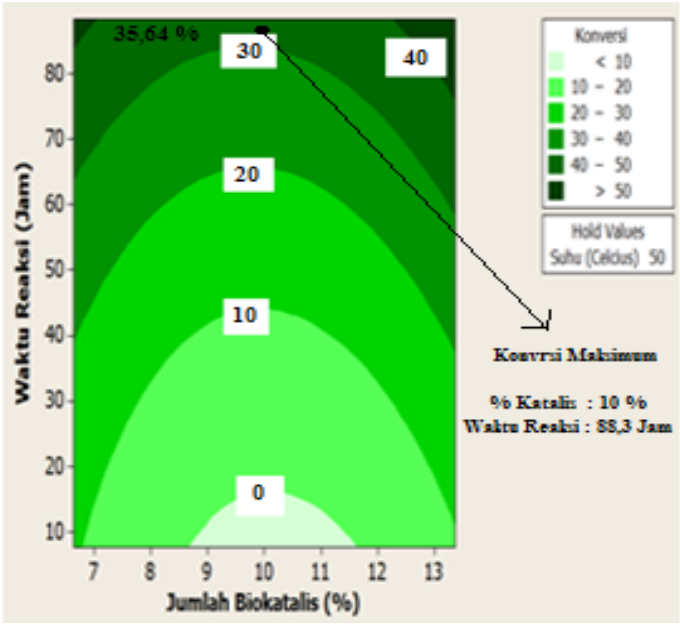

Gambar 3. Respon Kontur dari Plot Jumlah Biokatalis dan Waktu Reaksi terhadap konversi Asam Palmitat

Plot kontur menunjukkan bahwa jika jumlah biokatalis dipertahankan pada jumlah tertentu dan waktu reaksi ditingkatkan, maka mampu meningkatkan perolehan \% konversi 
surfaktan karbohidrat ester. Ketika jumlah biokatalis yang ditingkatkan dan waktu reaksi dipertahankan pada waktu tertentu, terlihat bahwa hal tersebut sedikit mempengaruhi perolehan konversi surfaktan karbohidrat ester.

Hasil penelitian pada permukaan kontur Gambar 3 di atas menunjukkan bahwa pada variabel tetap yaitu suhu $50{ }^{\circ} \mathrm{C}$, konversi maksimum diperoleh apabila jumlah biokatalis sebanyak $10 \%$ sedangkan waktu reaksi 88,3 jam. Pada kondisi reaksi ini diperoleh \% konversi surfaktan karbohidrat ester sebesar $35,64 \%$.

\section{Analisis Identifikasi Gugus Fungsi}

Spektroskopi FTIR merupakan alat untuk mendeteksi gugus fungsi suatu senyawa dengan spektrum infra merah dari senyawa organik yang memiliki sifat fisik yang khas. Energi radiasi inframerah akan diabsorpsi oleh senyawa organik sehingga molekulnya akan mengalami rotasi atau vibrasi. Setiap ikatan kimia yang berbeda seperti $\mathrm{C}-\mathrm{C}, \mathrm{C}-\mathrm{H}, \mathrm{C}=\mathrm{O}$, O$\mathrm{H}$ dan sebagainya mempunyai frekuensi vibrasi yang berbeda [5]. Adapun hasil spektrum fruktosa ester yang diperoleh ditunjukkan oleh gambar 4.

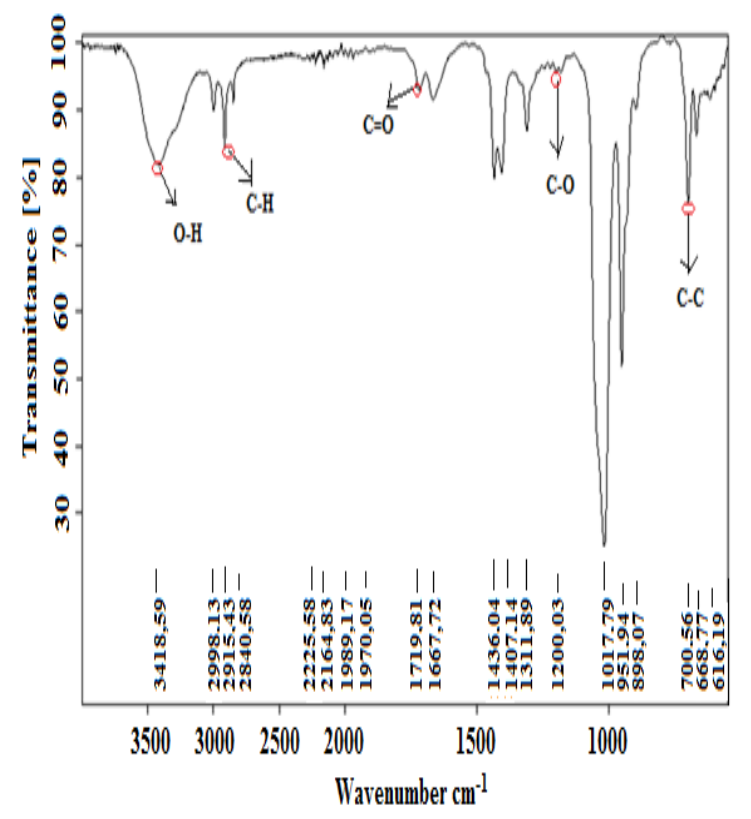

Gambar 4. Hasil Spektrum Fruktosa Ester dari Hasil Optimum

Pada Gambar 4 menunjukkan hasil analisis spektrum FTIR pada kondisi suhu $55^{\circ} \mathrm{C}$, jumlah biokatalis $12 \%$ dan waktu reaksi selama 72 jam yang memiliki konversi yang tertinggi. Pada gambar di atas menunjukkan bahwa produk fruktosa ester memiliki spektrum $3418 \mathrm{~cm}^{-1}$ (ikatan $\mathrm{OH})$. Vibrasi regangan metilen $\left(-\mathrm{CH}_{2}^{-}\right)$ muncul pada bilangan gelombang $2915 \mathrm{~cm}^{-1}$ sedangkan vibrasi regangan metin (- $\mathrm{CH}$ - tersier) muncul pada $2840 \mathrm{~cm}^{-1}, 1720 \mathrm{~cm}^{-1}$ (ikatan $\mathrm{C}=\mathrm{O}$ pada ester), $1436 \mathrm{~cm}^{-1}$ (ikatan C-H pada $\mathrm{R}-\mathrm{CH}_{3}$ atau $\mathrm{R}-\mathrm{CH}_{2}-\mathrm{R}$ ), $1200 \mathrm{~cm}^{-1}$ (ikatan C-O-C pada cincin gula) dan $700 \mathrm{~cm}^{-1}$ (ikatan $\mathrm{C}-\mathrm{C}$ pada $\left.\mathrm{R}\left(\mathrm{CH}_{2}\right)_{4}-\mathrm{C}\right)$. Adanya gugus $\mathrm{C}=\mathrm{O}$ dan $\mathrm{C}-\mathrm{O}$ ini menunjukkan sampel mengandung senyawa ester. Hal ini disebabkan reaksi sintesis surfaktan fruktosa ester juga terdapat reaksi samping berupa terbentuknya ester mempunyai tekukan yang rendah untuk kondisi operasi ini, reaksi samping yang terjadi sedikit.

Selain analisis identifikasi gugus fungsi pada surfaktan yang dihasilkan, ada beberapa analisis lainnya yang dilakukan seperti bilangan asam, bilangan penyabunan, penentuan nilai HLB dan tegangan permukaan. Bilangan asam yang diperoleh dari kondisi produk yang terbaik adalah 6,28. Bilangan penyabunan yang diperoleh dari kondisi produk yang terbaik adalah 2,954. Sedangkan nilai HLB produk surfaktan dari kondisi terbaik diperoleh sebesar 10,592 yang digunakan sebagai pengemulsi minyak dalam air. Diperoleh juga dari produk surfaktan yang dihasilkan dapat menurunkan tegangan permukaan sebesar 41,0609 dyne/cm atau $56,36 \%$.

\section{Kesimpulan}

1. Nilai determinasi yang dihasilkan sebesar 92,33\% menunjukkan validitas untuk variabel penelitian.

2. Variabel yang paling berpengaruh berturut-turut adalah waktu reaksi, suhu dan jumlah biokatalis berdasarkan hasil analisis statistik pada software Minitab.

3. Kondisi optimasi terbaik diperoleh pada kondisi suhu $55^{\circ} \mathrm{C}$, jumlah biokatalis $12 \%$ dan waktu reaksi selama 72 jam dimana konversi asam palmitat yang didapat adalah $61,80 \%$ dan dapat menurunkan tegangan permukaan sebesar 41,0609 dyne/cm atau sebesar 56,36\%.

\section{Daftar Pustaka}

[1] A.M. Gumel, M.S.M. Annuar, T. Heidelberg, and Y. Chisti, Lipase Mediated Synthesis of Sugar Fatty Acid Esters, Process Biochemistry 46, 2079 2090, 2011.

[2] B.D. Ribeiro, Aline Machado de Catro, Maria Alice Zarur Coelho, and Denise Maria Guimaraes Freire, Production and Use of Lipases in Bioenergy : A Review from the Feedstocks to Biodiesel Production, Enzyme Research Article ID 615803, 2011. 
[3] C. Hidayat, Kholifaturrosyidah Fitria, Supriyanto, and Pudji Hastuti, Enzymatic Synthesis of Bio - Surfactant Fructose Oleic Ester Using Immobilized Lipase on Modified Hydrophobic Matrix in Fluidized Bed Reactor, Agriculture and Agricultural Science Procedia 9353 - 362, 2016.

[4] Chemmunique, The HLB SYSTEM a Time - Saving Guide to Emulsifier Selection, ICI Americas Inc, USA, p.22, 1980.

[5] F. Bastian, Skripsi, Pemurnian Surfaktan Nonionik Alkil Poliglioksida (APG) Berbasis Tapioka dan Dodekanol, Institut Pertanian Bogor, 2011.

[6] G. Hellner, Dissertation, Application of Lipolytic Enzymes of Microbial Origin as Biocatalysts, Corvinus University of Budapest, 2011.

[7] J.S. White, Sucrose, HFCS, and Fructose: History, Manufacture, Composition, Applications and Production, White Techinical Research, USA (2014), p. 1333.

[8] L. Adamopoulos, Thesis, Understanding the Formation of Sugar Fatty Acid Esters, North Carolina State University, 2006.

[9] N.S. Neta, Antonio M. Peres, Jose A. Teixeira, and Ligia R. Rodrigues, Maximization of Fructose Esters Synthesis by Response Surface Methodology, New Technology Vol.28, 349 - 355, 2011.

[10] P.P. Dandekar and V.B. Patravale, Enzymatic Synthesis of Fructose Ester from Mango Kernel Fat, Indian Journal of Chemical Technology Vol. 16, 317 - 321, 2009.

[11] P. Mangalorkar, Madhavi Patel, Anamik Shah, and Padamnabhi Nagar, Chemical Profiling of Taverniera Cuneifolia (ROTH) Ali , A Possible Substitute of Glycyrrhiza Glabra L By GC-MS, World Journal of Pharmaceutical Research Vol. 5, 547 552, 2015.

[12] P. Tufvesson, Annika Annerling, Rajni Hatti-Kaul, and Dietlind Adlercreutz, Solvent-Free Enzymatic Synthesis of Fatty Alkanolamides, Biotechnology and Bioengineering Vol. 97 No.3, 2006.

[13] R.J. Farn, Chemistry and Technology of Surfactants, Blackwell Publishing, USA, p. 315, 2006.

[14] R. Pichot, Thesis, Stability and Characterisation of Emulsions in the Presence of Colloidal Particles and
Surfactants, University of Birmingham, 2010.

[15] R. Sharma, Yusuf Chisti, and Utam Chand Banerjee, Production, Purification, Characterization and Applications of Lipases, Biotechnology Advances 19, 627 $-662,2001$.

[16] T. Vitisant, Warawut Chulalaksananukul, Rungtiwa Piumthongkum, Nusara Sinbuathong, Puttachad Mekthong, and Suphang Chulalaksananukul, Synthesis of Sugar Ester by Local Yeast Lipase in Solvent Free System, International Journal of Science and Technology Vol.2 No. 11 2012.

[17] X. Xu, L. Fomuso, and C. Akoh, Synthesis of Structured Triacylglycerols by Lipase Catalyzed Acidolysis in a Packed Bed Bioreactor. Journal Agric, Food Chem Vol. 48, 3-10, 2000. 